\title{
Biochemical and thermal characterization of crude exo-polygalacturonase produced by Aspergillus sojae
}

\author{
Canan Tari ${ }^{\mathrm{a}, *}$, Nergiz Dogan ${ }^{\mathrm{b}}$, Nihan Gogus ${ }^{\mathrm{a}}$ \\ ${ }^{a}$ Department of Food Engineering, Izmir Institute of Technology, Gulbahce, Urla, Izmir 35430, Turkey \\ ${ }^{\mathrm{b}}$ Biotechnology and Bioengineering Programme, Izmir Institute of Technology, Urla, Izmir 35430, Turkey
}

\section{A R T I C L E I N F O}

\section{Article history:}

Received 19 February 2008

Received in revised form 13 March 2008

Accepted 24 April 2008

\section{Keywords:}

Polygalacturonase

Aspergillus sojae

Biochemical and thermal properties

Microbial enzymes

Enzyme characterization

\begin{abstract}
A B S T R A C T
Crude exo-polygalacturonase enzyme (produced by Aspergillus sojae), significant for industrial processes, was characterized with respect to its biochemical and thermal properties. The optimum $\mathrm{pH}$ and temperature for maximum crude exo-polygalacturonase activity were $\mathrm{pH} 5$ and $55^{\circ} \mathrm{C}$, respectively. It retained $60-70 \%$ of its activity over a broad $\mathrm{pH}$ range and $80 \%$ of its initial activity at $65^{\circ} \mathrm{C}$ for $1 \mathrm{~h}$. The thermal stability study indicated an inactivation energy of $E_{\mathrm{d}}=152 \mathrm{~kJ} \mathrm{~mol}^{-1}$. The half lives at 75 and $85^{\circ} \mathrm{C}$ were estimated as 3.6 and $1.02 \mathrm{~h}$, respectively. Thermodynamic parameters, $\Delta H^{*}, \Delta S^{*}$ and $\Delta G^{*}$, were determined as a function of temperature. The kinetic constants $K_{\mathrm{m}}$ and $V_{\max }$, using polygalacturonic acid as substrate, were determined as $0.424 \mathrm{~g} \mathrm{l}^{-1}$ and $80 \mu \mathrm{mol} \mathrm{min}^{-1}$, respectively. SDS-PAGE profiling revealed three major bands with molecular weights of 36,53 and $68 \mathrm{kDa}$. This enzyme can be considered as a potential candidate in various applications of waste treatment, in food, paper and textile industries.
\end{abstract}

(c) 2008 Elsevier Ltd. All rights reserved.

\section{Introduction}

Pectic substances, mainly degraded by pectolytic enzymes, contribute to the firmness and structure of plant cells (Naidu \& Panda, 2003). These enzymes are of multiple nature and various forms due to the complex nature of their substrates. Endo-polygalacturonase (PGL, EC 3.2.1.15), exo-PGL (EC 3.2.1.67), pectate lyase (EC 4.2.2.2), pectin lyase (EC 4.2.2.10) and pectin methyl esterase (EC 3.1.1.11) form a consortium of enzymes which are necessary for the hydrolysis of pectin (Gadre, Driessche, Beeumen, \& Bhat, 2003). Pectolytic enzymes of fungal origin attract the most attention since they offer tremendous potential to the industry. Some of their applications are in retting of flax and vegetable fibres, de-pectinisation and clarification of fruit juices, extraction of oils from vegetables and citrus peels, manufacturing of paper and pulp and pre-treatment of pectic waste water (Hoondal, Tiwari, Tiwari, Dahiya, \& Beg, 2002; Jayani, Saxena, \& Gupta, 2005; Moyo, Gashe, Collison, \& Mpuchane, 2003; Saito, Takakuwa, \& Oda, 2004). Almost all of the commercial preparations of pectinases are produced from fungal sources, mainly from Aspergillus niger. In fact microbial pectinases account for almost $25 \%$ of the global food enzyme sales (Jayani et al., 2005). It is also observed that applications of pectinases in various fields are increasing, demanding the discovery of new strains producing pectinases with novel properties. Therefore, it is highly important to determine these characteristics for an efficient application.

\footnotetext{
* Corresponding author. Tel.: +90 232 7506316; fax: +90 2327506196

E-mail address: canantari@iyte.edu.tr (C. Tari).
}

Hence, the objective of this study was to determine the biochemical and thermal properties of the crude exo-polygalacturonase (from here on for simplicity polygalacturonase only) mostly considered among pectinases. This enzyme was produced by Aspergillus sojae ATCC 20235, not recognized so far. In our previous work (Gogus, Tari, Unluturk, Oncu, \& Tokatlı, 2006; Tari, Gogus, \& Tokatlı, 2007; Ustok, Tari, \& Gogus, 2007), we reported that the organism exhibits a major potential for the production of this enzyme in submerged and solid state fermentation. Therefore, this paper will complement our previous studies.

In fact, the search for polygalacturonases with new industrial potential requires the discovery of new microbial strains and an understanding of the structure-stability relationship of this enzyme. The knowledge gained, will improve the potential and its effective usage in such diverse and broad areas. Furthermore, it will help to establish additional information required to maintain the desired level of enzyme activity over a long period of time and improve its stability. These are important parameters taken into account in the selection and design of enzymes (Gummadi \& Panda, 2003). In this study characterization of the crude enzyme was considered, since the crude enzyme application can offer advantages in certain circumstances. For example, the collaborative action of different pectolytic enzymes in a crude enzyme sample preparation can increase the overall yield of the extraction or clarification process in the fruit juice industry. In fact a brief comparison of the crude enzyme with the purified enzyme, using three-phase partitioning (Dogan \& Tari, 2008), is given at the end of this paper. It has been reported that a crude enzyme is more stable than a 


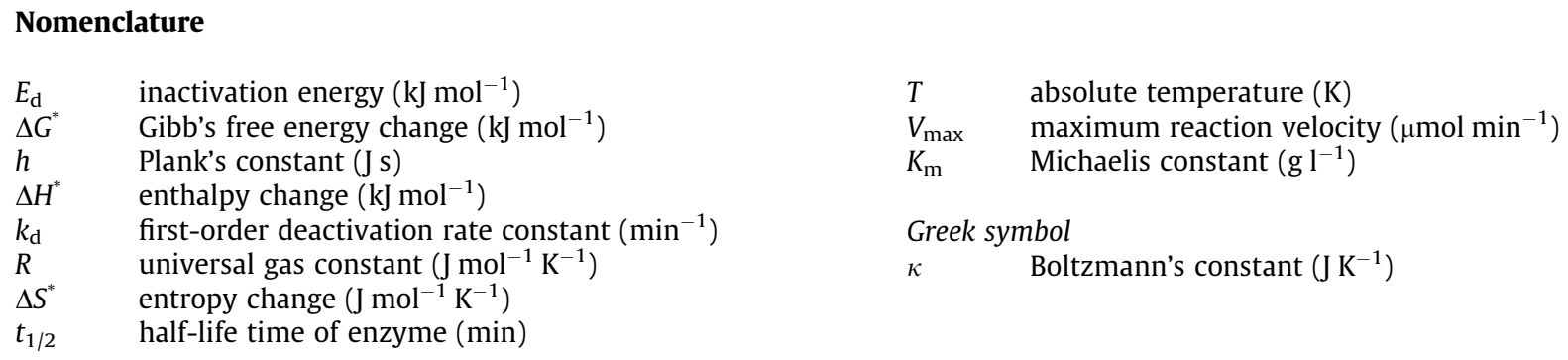

$T \quad$ absolute temperature (K)

$V_{\max } \quad$ maximum reaction velocity $\left(\mu \mathrm{mol} \mathrm{min}^{-1}\right)$

$K_{\mathrm{m}} \quad$ Michaelis constant $\left(\mathrm{g}^{-1}\right)$

Greek symbol

$\kappa \quad$ Boltzmann's constant $\left(\mathrm{J} \mathrm{K}^{-1}\right)$

purified enzyme (Naidu \& Panda, 2003). This observation was in agreement with our own results, highlighted in this paper.

\section{Materials and methods}

\subsection{Microorganism and development of inoculum}

Aspergillus sojae ATCC 20235 was purchased from Promochem Inc., an international distributor of ATCC (American Type of Culture Collection) in Europe. The propagation was done on yeast malt extract (YME) agar and incubated at $30{ }^{\circ} \mathrm{C}$ until sporulation. Stock cultures were prepared in $20 \%$ glycerol water and stored at $-80^{\circ} \mathrm{C}$.

The spore suspensions used as inoculum were obtained on molasses agar slants, described in Tari et al. (2007).

All the analytical grade materials and the culture media ingredients were obtained from Sigma Aldrich.

\subsection{Production of polygalacturonase}

The production of polygalacturonase was done in shaken flasks (50 $\mathrm{ml}$ in $250 \mathrm{ml}$ Erlenmeyer) containing glucose $\left(25 \mathrm{~g} \mathrm{l}^{-1}\right)$, peptone $\left(2.5 \mathrm{~g} \mathrm{l}^{-1}\right)$, disodium phosphate $\left(3.2 \mathrm{~g} \mathrm{l}^{-1}\right)$, monosodium phosphate $\left(3.3 \mathrm{~g} \mathrm{l}^{-1}\right)$ and maltrin $\left(120 \mathrm{~g} \mathrm{l}^{-1}\right)$. The fermentation was conducted at $350 \mathrm{rpm}$ at $30^{\circ} \mathrm{C}$ for $96 \mathrm{~h}$. After this time, each flask was assayed for polygalacturonase enzyme activity. Enzyme activity was determined on supernatant obtained after the centrifugation of the broth at $6000 \mathrm{rpm}$ for $15 \mathrm{~min}$.

\subsection{Enzyme assay}

Polygalacturonase activity was defined and assayed according to the procedure given by Panda, Naidu, and Sinha (1999), using polygalacturonic acid as substrate at $\mathrm{pH} 6.6$ and $26^{\circ} \mathrm{C}$.

\subsection{Protein determination}

The total protein contents of samples were determined according to the method reported by Lowry, Rosebrough, Farr, and Randall (1951); the protein standard used was bovine serum albumin.

\subsection{SDS-PAGE profiling}

SDS-PAGE was performed according to the procedure described by Laemmli (1970) using 10\% resolving and 5\% stacking gel. Protein bands were visualized using Coomassie brilliant blue R250 and methanol-water (containing 10\% acetic acid) as staining and destaining agents, respectively. Fermentas SM0661 was used as the molecular weight marker, with the broad range of 10-200 kDa.

\subsection{Effect of $\mathrm{pH}$ on activity and stability}

The effect of $\mathrm{pH}$ on the activity of polygalacturonase was determined by assaying the enzyme activity at different $\mathrm{pH}$ values rang- ing from 3.0 to 7.0 , using $0.1 \mathrm{M}$ concentrations of the following buffer systems: citrate $(\mathrm{pH} 3.0)$, acetate $(\mathrm{pH} 4.0,5.0)$ and phosphate ( $\mathrm{pH} 6.0,7.0)$. The relative activities were based on the ratio of the activity obtained at a certain $\mathrm{pH}$ to the maximum activity obtained at that range and expressed as a percentage. The $\mathrm{pH}$ stability of $A$. sojae polygalacturonase was investigated in the $\mathrm{pH}$ range 3.0-8.0, using $0.1 \mathrm{M}$ citrate $(\mathrm{pH} 3.0)$, acetate $(\mathrm{pH} \mathrm{4.0,5.0)}$ and phosphate $(\mathrm{pH} \mathrm{6.0,7.0,8.0)}$ buffer systems. Therefore, $2 \mathrm{ml}$ of the crude enzyme were mixed with $2 \mathrm{ml}$ of the buffer solutions indicated above and incubated at $30^{\circ} \mathrm{C}$ for $2 \mathrm{~h}$. After this period, aliquots of the mixtures were taken to measure the residual polygalacturonase activity (\%) with respect to control, under standard assay conditions.

\subsection{Effect of temperature on activity and stability}

In order to determine the effect of temperature on the activity of polygalacturonase, the standard polygalacturonase assay procedure at different temperatures, ranging from 25 to $75^{\circ} \mathrm{C}(25,37,45,55,65$ and $75^{\circ} \mathrm{C}$ ), was performed. Prior to the addition of the enzyme, the substrate $(0.24 \%(\mathrm{w} / \mathrm{v})$ polygalacturonic acid) was pre-incubated at the respective temperature for $10 \mathrm{~min}$. The relative activities as percentages, were expressed as the ratio of the polygalacturonase activity at a certain temperature to the maximum activity at the given temperature range. The thermostability of the crude polygalacturonase was investigated by measuring the residual activity after incubating the enzyme at various temperatures ranging from 25 to $65^{\circ} \mathrm{C}$ $\left(25,37,45,55\right.$ and $\left.65^{\circ} \mathrm{C}\right)$ for 30 and $60 \mathrm{~min}$.

\subsection{Kinetics of thermal inactivation and estimation of the inactivation energy}

In order to study the thermal inactivation kinetics of polygalacturonase, the crude enzyme was incubated at different temperatures $\left(75,80,82.5\right.$ and $\left.85^{\circ} \mathrm{C}\right)$ in the absence of the substrate. At periodic intervals, aliquots were withdrawn and cooled in an ice bath prior to assay as described above. The residual activity was expressed as percent of the initial activity. The inactivation rate constants $\left(k_{\mathrm{d}}\right)$ were calculated from slopes of a semilogarithmic plot of residual activity versus time and apparent half lives were estimated using Eq. (1). The time where the residual activity reaches $50 \%$ is known as the half-life

$t_{1 / 2}=\frac{\ln 2}{k_{\mathrm{d}}}$.

The temperature dependence of $k_{\mathrm{d}}$ was analyzed using the Arrhenius plot (Shuler \& Kargi, 2002). The inactivation energy was calculated from the Arrhenius equation as

$\ln \left(k_{\mathrm{d}}\right)=\ln \left(k_{0}\right)-\left(\frac{E}{R}\right) \frac{1}{T}$.

The values of $E$ and $k_{0}$ were estimated from the slope and intercept of the plot of $\ln \left(k_{\mathrm{d}}\right)$ versus $1 / T$, respectively. 


\subsection{Estimation of thermodynamic parameters}

The enthalpy of inactivation $\left(\Delta H^{*}\right)$ for each temperature was calculated according to Eq. (3)

$\Delta H^{*}=E_{\mathrm{d}}-R T$.

The values for the Gibb's free energy $\left(\Delta G^{*}\right)$ of inactivation at different temperatures were calculated from the first-order constant of inactivation process by using Eq. (4)

$\Delta G^{*}=-R T \ln \left(\frac{k_{\mathrm{d}} h}{\kappa T}\right)$.

From Eqs. (3) and (4) the entropy of inactivation $\left(\Delta S^{*}\right)$ of polygalacturonase was calculated from Eq. (5)

$\Delta S^{*}=\frac{\left(\Delta H^{*}-\Delta G^{*}\right)}{T}$.

\subsection{Determination of kinetic constant}

A Lineweaver-Burk double reciprocal $(1 / V$ versus $1 / S)$ plot (Shuler \& Kargi, 2002) was used in order to determine the kinetic constants ( $V_{\max }$ and $K_{\mathrm{m}}$ ), where different concentrations of polygalacturonic acid were used as substrate $\left(0.125-1 \mathrm{mg} \mathrm{ml}^{-1}\right)$ at $\mathrm{pH} 6.6$

$\frac{1}{v}=\frac{1}{V_{\mathrm{m}}}+\frac{K_{\mathrm{m}}}{V_{\mathrm{m}}} \frac{1}{[S]}$

With a slope of $K_{\mathrm{m}} / V_{\mathrm{m}}$ and intercept of $1 / V_{\mathrm{m}}$ (Eq. (6)), $K_{\mathrm{m}}$ and $V_{\mathrm{m}}$ values were estimated.

\section{Results and discussion}

\subsection{Effect of $\mathrm{pH}$ on polygalacturonase activity and stability}

As is seen from Fig. 1a, the enzyme was active over a broad $\mathrm{pH}$ range, displaying over $80 \%$ of its activity in the $\mathrm{pH}$ range $5.0-7.0$.
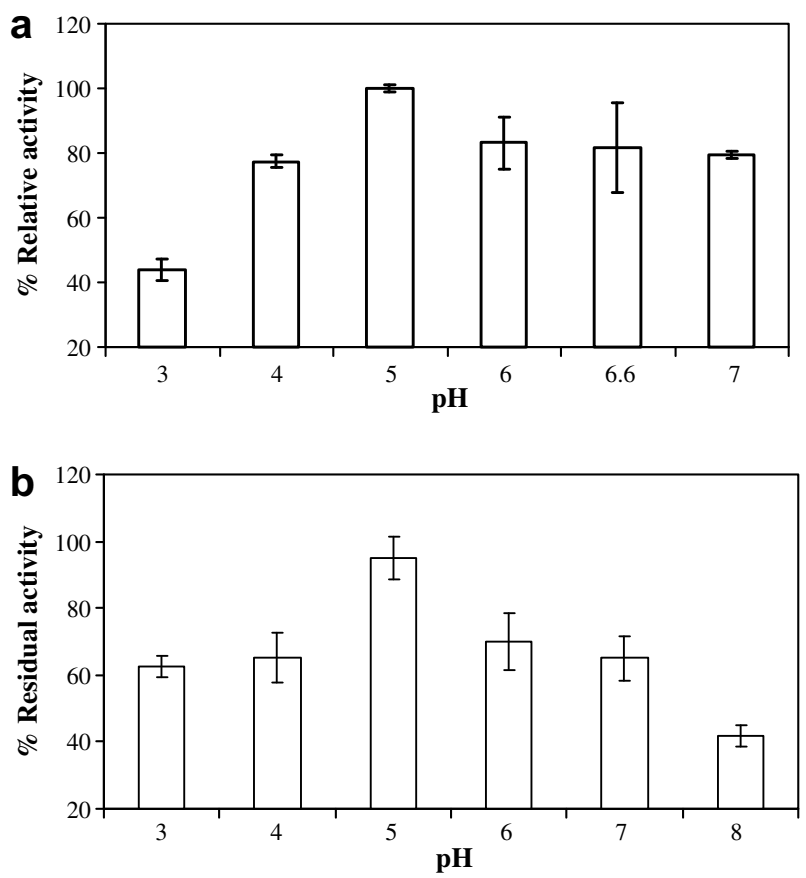

Fig. 1. Effect of pH on A. sojae PG (a) activity and (b) stability. Each experiment was carried out twice and the standard deviations of relative and residual polygalacturonase activity were $4.8 \%$ and $16.5 \%$, respectively.
Optimum polygalacturonase activity was observed at $\mathrm{pH}$ 5. However, a further decrease from $\mathrm{pH} 5.0$ to 3.0 decreased the polygalacturonase activity rapidly to $40 \%$ relative activity. These findings were in agreement with several studies where a $\mathrm{pH}$ optimum of 4.8 for polygalacturonase from Aspergillus niger, a pH optimum of 5.0 for Aspergillus awamori and a pH optimum of 4-5.5 for Aspergillus japonicus was reported (Jayani et al., 2005; Gummadi \& Panda, 2003). It has been indicated that, among the polygalacturonases obtained from different microbial sources, most have an optimal $\mathrm{pH}$ range of 3.5-5.5 (Jayani et al., 2005). With an optimum $\mathrm{pH}$ of 5.0 , A. sojae polygalacturonase could be applicable to fruit juice industries and wine making. It is well known that acidic pectinases mostly originate from fungal sources, especially from A. niger (Kashyap, Vohra, Chopra, \& Tewari, 2001).

The effect of $\mathrm{pH}$ on stability (Fig. 1b) showed that the polygalacturonase enzyme was very stable at $\mathrm{pH} 5.0$ and retained $60 \%$ and $70 \%$ of its activity at pH 3.0 and 7.0 , respectively. The enzyme lost about $60 \%$ of its activity at $\mathrm{pH} 8.0$. Therefore, polygalacturonase like the one characterized in this study could be a potential candidate for different applications in the industry requiring broader $\mathrm{pH}$ stability ranges.

\subsection{Effect of temperature on activity and stability of polygalacturonase}

The crude polygalacturonase was found to have an optimum temperature of $55^{\circ} \mathrm{C}$ (Fig. 2a). The enzyme retained $75 \%$ of its activity at 65 and $75^{\circ} \mathrm{C}$. The polygalacturonase was active over a broad temperature range of $25-75^{\circ} \mathrm{C}$. As a close comparison, the optimum temperature of the commercial enzyme Rapidase C80 was determined at $55^{\circ} \mathrm{C}$ as well (Ortega, de Diego, Perez-Mateos, \& Busto, 2004). Similarly, in another study, the optimum temperature for $A$. niger polygalacturonase was reported to be $60^{\circ} \mathrm{C}$. This value was slightly higher than the partially purified polygalacturonase from Sporotrichum thermophile Apinis, having an optimum temperature of $55{ }^{\circ} \mathrm{C}$ (Jayani et al., 2005; Kashyap et al., 2001; Sakamoto, Bonnin, Quemener, \& Thibault, 2002).

Thermostability of an enzyme is defined as the ability to resist thermal unfolding in the absence of substrates (Bhatti, Ashger,
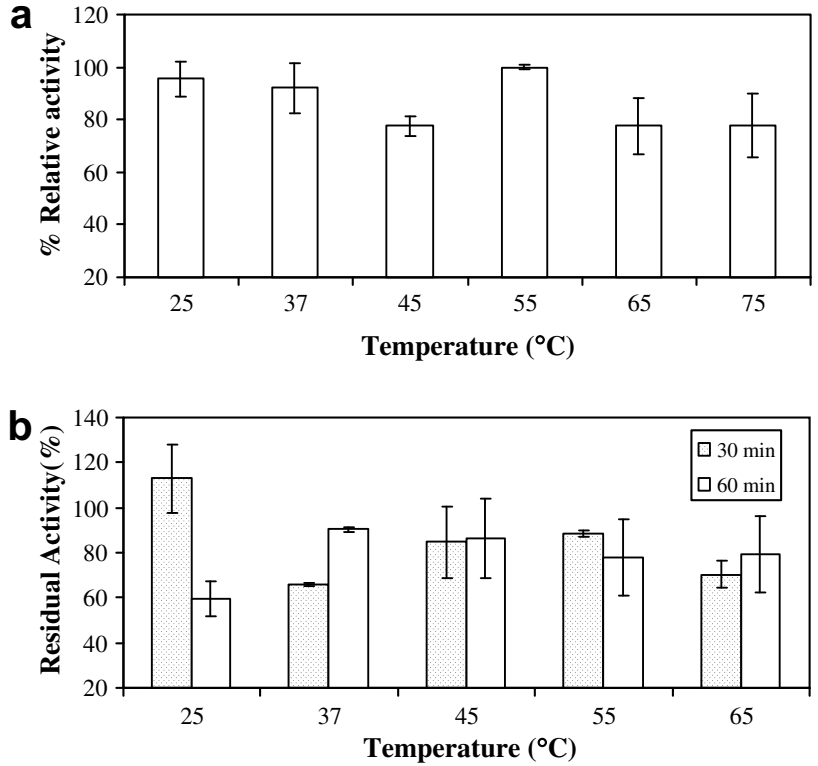

Fig. 2. Effect of temperature on A. sojae PG (a) activity and (b) stability. Each experiment was carried out twice and the standard deviations of relative and residual polygalacturonase activity were $11.3 \%$ and $15.2 \%$, respectively. 
Abbas, Nawas, \& Sheikh, 2006). The thermostability of the polygalacturonase was measured using the residual activity of the enzyme after incubation at various temperatures ranging from 25 to $65^{\circ} \mathrm{C}$ for 30 and $60 \mathrm{~min}$ (Fig. 2b). The enzyme was stable at $25{ }^{\circ} \mathrm{C}$ for $30 \mathrm{~min}$ of incubation, whereas $40 \%$ of its activity was lost after $1 \mathrm{~h}$. This confirms that this enzyme favours higher temperatures as can be observed from the stability data at $37,45,55$ and $65{ }^{\circ} \mathrm{C}$. It has a residual activity ranging from $65 \%$ to $80 \%$ when incubated at these temperatures for 30 and $60 \mathrm{~min}$. The thermostability of pectinases is an important parameter, especially in fruit juice extraction. Before the addition of pectinases, fruits are first cooked to release more juice. This releases most of the pectin into the juice, resulting in a thick and a cloudy appearance. Apples, stone fruits and berries are normally processed at $30-50{ }^{\circ} \mathrm{C}$ for about 15 to 90 min (Moyo et al., 2003). Therefore, A. sojae polygalacturonase has great potential to be used primarily in the fruit juice industry, because it is thermostable up to $65^{\circ} \mathrm{C}$ for an hour. Since, after any application, the enzyme has to be inactivated, the estimation of thermal inactivation discussed in the next section has great importance.

\subsection{Kinetics of thermal inactivation and estimation of the inactivation energy}

The process whereby the secondary, tertiary or quaternary structure of a protein changes without breaking covalent bonds is defined as inactivation (Naidu \& Panda, 2003). Inactivation rate constants $\left(k_{\mathrm{d}}\right)$ of polygalacturonase, presented in Table 1 at 75 , $80,82.5$ and $85^{\circ} \mathrm{C}$, were calculated from the slope of the semilogarithmic plot of residual activity versus time. Likewise, the half-life values estimated using these constants and Eq. (1), are presented in the same Table. The half-life of polygalacturonase at $75^{\circ} \mathrm{C}$ was 2.25, 4.97 and 3.53 times higher than the half-life values at temperatures of $80,82.5$ and $85^{\circ} \mathrm{C}$, respectively. This issue reveals the thermal stability of this enzyme at $75^{\circ} \mathrm{C}$ and its easy inactivation at higher temperatures.

Inactivation energy of the crude polygalacturonase was determined as $E_{\mathrm{d}}=152 \mathrm{~kJ} \mathrm{~mol}^{-1}$ from the slopes of the linear curve plotted by $1 / T$ versus $\ln k_{\mathrm{d}}$ using Eq. (2). This value was in close approximation to the values $\left(167-293 \mathrm{~kJ} \mathrm{~mol}^{-1}\right)$ estimated for many microbial enzymes (Shuler \& Kargi, 2002). The inactivation energy estimated for this enzyme was $1.05,0.92$ and 0.96 times higher than the commercial polygalacturonases Rapidase C80, Pectinase CCM and Pectinex 3XL, respectively (Ortega et al., 2004). These close approximations indicated that the crude enzyme can be considered as a potential candidate for various industrial applications.

\subsection{Estimation of thermodynamic parameters during inactivation of polygalacturonase}

The changes in enthalpy $\left(\Delta H^{*}\right)$ and entropy $\left(\Delta S^{*}\right)$ are calculated using transition state theory (Ortega et al., 2004) according to Eqs. (3) and (5) for the thermal inactivation of polygalacturonase (Table 2). A positive $\Delta H^{*}$ and $\Delta S^{*}$ were determined in the tempera-

Table 1

Kinetic parameters for thermal inactivation of polygalacturonase from A. sojae

\begin{tabular}{llc}
\hline$T\left({ }^{\circ} \mathrm{C}\right)$ & $k_{\mathrm{d}}\left(\mathrm{min}^{-1}\right)$ & $t_{1 / 2}(\mathrm{~min})$ \\
\hline 75 & 0.0032 & 216.60 \\
80 & 0.0074 & 93.69 \\
82.5 & 0.0159 & 43.59 \\
85 & 0.0113 & 61.34 \\
\hline
\end{tabular}

From slope of the semilogarithmic plot of residual activity versus time for each temperature, the inactivation rate constants $\left(k_{\mathrm{d}}\right)$ were calculated $\left(R^{2}=0.94\right.$ for $85^{\circ} \mathrm{C}, R^{2}=0.90$ for $82.5^{\circ} \mathrm{C}, R^{2}=0.96$ for $80^{\circ} \mathrm{C}$ and $R^{2}=0.83$ for $75^{\circ} \mathrm{C}$ )
Table 2

Thermodynamic parameters of thermal inactivation of polygalacturonase from $A$. sojae at different temperatures

\begin{tabular}{llll}
\hline$T(K)$ & $\Delta H^{*}\left(\mathrm{~kJ} \mathrm{~mol}^{-1}\right)$ & $\Delta G^{*}\left(\mathrm{~kJ} \mathrm{~mol}^{-1}\right)$ & $\Delta S^{*}\left(\mathrm{~J} \mathrm{~mol}^{-1} \mathrm{~K}^{-1}\right)$ \\
\hline 348 & 149 & 102 & 134 \\
353 & 149 & 99.9 & 139 \\
355.5 & 149 & 97.7 & 144 \\
358 & 149 & 98.7 & 140 \\
\hline
\end{tabular}

ture ranges studied. With increase of temperature, a slight decrease in $\Delta H^{*}$ and a marked increase in $\Delta S^{*}$ were observed. This suggested thermal denaturation of the enzyme, possibly due to disruption of non-covalent linkages, including hydrophobic interactions (Bhatti et al., 2006; Georis et al., 2000). The opening up of the enzyme structure was in fact confirmed by the increase in the entropy or disorder of inactivation (Bhatti et al., 2006). The increase in $\Delta S^{*}$ also indicated an increase in number of protein molecules in transition activated stage, resulting in lower values of $\Delta G^{*}$. Also, positive entropy values suggested that enzyme unfolding might be the rate determining step for the irreversible thermo-inactivation of polygalacturonase. Moreover, solvent and structural effects are reported to be the two major factors influencing the numerical values of $\Delta H^{*}$ and $\Delta S^{*}$. Particularly, $\Delta S^{*}$ values are known to provide information regarding the degree of solvation and the degree of compactness of protein molecule (Dogan \& Tari, 2008). Also the increase in the $\Delta H^{*}$ with respect to temperature increase reveals that the conformation of the enzyme was altered. The current results were in very close agreement with the results reported by Ortega et al. (2004) using commercial pectinases such as Rapidase C80, Pectinase CCM and Pectinex 3XL. In fact this is a positive outcome since we demonstrated that the polygalacturonase in the current study is very close in biochemical, as well as in thermal, characteristics, to commercial enzymes currently used.

\subsection{Calculation of kinetic constants}

The kinetic parameters of polygalacturonase, describing its affinity towards polygalacturonic acid (PGA) at pH 6.6 and $26^{\circ} \mathrm{C}$ were obtained by a typical double reciprocal Lineweaver Burk plot (Eq. (6)). The apparent $K_{\mathrm{m}}$ value and $V_{\mathrm{m}}$ value for hydrolyzing PGA were $V_{\mathrm{m}}=80 \mu \mathrm{mol} \mathrm{min}-1, K_{\mathrm{m}}=0.424 \mathrm{~g} \mathrm{l}^{-1}$, respectively. The estimated $K_{\mathrm{m}}$ value was 1.7 and 1.87 times lower than the $A$. niger and Sclerotinia sclerotiorum polygalacturonases, respectively. This indicates that the current polygalacturonase has a higher affinity for PGA than the other two (Jayani et al., 2005). A similar $K_{\mathrm{m}}$ value $\left(0.416 \mathrm{~g} \mathrm{l}^{-1}\right)$ was reported in a study conducted using Sporotrichum thermophile polygalacturonase (Kaur, Kumar, \& Satyanarayana, 2004). Another study with $A$. niger polygalacturonase indicated a $V_{\mathrm{m}}$ value of $154 \mu \mathrm{mol} \mathrm{min}{ }^{-1}$ which is in correlation with our results (Singh \& Rao, 2002).

\subsection{SDS-PAGE profiling}

SDS-PAGE profiling (Fig. 3) revealed that the crude enzyme was composed of three main fractions with molecular weights of 36,53 and $68 \mathrm{kDa}$, respectively. The first two bands were observed after the purification step by means of three-phase partitioning as well (Gummadi \& Panda, 2003). These bands could indicate the presence of isozymes, different proteins or impurities. The identifications remain a task to perform in future. Two different polygalacturonases with different molecular weights, such as 38 and $61 \mathrm{kDa}$; 38, and $65 \mathrm{kDa}, 63$ and $79 \mathrm{kDa}$ were reported for $A$. niger, A. japonicus and Penicillium frequentans, respectively (Jayani et al., 2005). Therefore, the current enzyme will be a new example in the literature. 


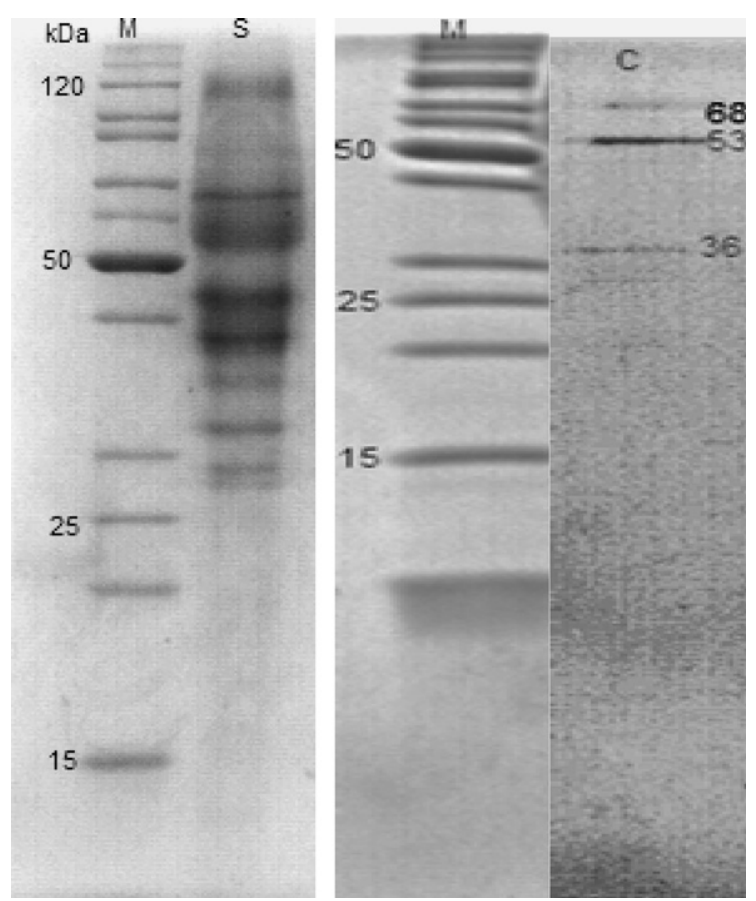

Fig. 3. SDS-PAGE of crude polygalacturonase (PG). Lane M, marker proteins; lane S, standard pectinases; lane $C$, crude extract. The amount of protein loaded in each sample lane was $20 \mu \mathrm{g}$.

\subsection{Comparison of crude and purified polygalacturonase}

Crude polygalacturonase was purified by a three-phase partitioning (TPP) procedure, a combination of ammonium sulphate and tert-butanol, to precipitate proteins from crude extracts as a single purification step (Dogan \& Tari, 2008). In the comparison of the two enzymes (crude and purified enzyme using TPP), the optimum $\mathrm{pH}$ and temperatures were very close, with slight differences that could be related to the composition of the two enzyme systems used. It is also assumed that these results could be linked to the degree of purification applied. Perhaps, this procedure might not have been sufficient to eliminate some of the potential interfering substances affecting the activity. Furthermore, other proteins or impurities, as apparent in the SDS-PAGE profiling discussed above (Section 3.6), revealed this fact. However, the thermodynamic study revealed that the crude polygalacturonase was more stable than was the purified polygalacturonase. This observation was also reported by Naidu and Panda (2003), who explained this by the interactive effects among the three enzyme components, or proteins other than those components secreted by the organism and/or a combination of the two. Considering the kinetic parameters, the purified polygalacturonase showed a higher $K_{\mathrm{m}}$ value than the crude polygalacturonase. This could be a result of the presence of the other polygalacturonases that could not been purified by the three-phase partitioning method. A similar conclusion is also drawn from the $V_{\mathrm{m}}$ values, revealing a lower catalytic activity of the purified polygalacturonase. Finally, the biochemical and thermal characteristics of these two enzyme systems are clearly different. This signifies the importance of the application of crude versus purified enzymes in the industry.

As is known, pectinases have considerable industrial applications in several conventional processes, such as those for textiles, tea, coffee, oil extraction, fruit juice extraction and clarification. In fruit juice extraction, pectinases have been used in combination with enzymes such as cellulases, xylanases and arabinases to increase the pressing efficiency. Besides the food industry, pectinases have been used, together with cellulases, hemicellulases, amylases and lipases, in the textile industry (Jayani et al., 2005). Crude polygalacturonase extract can have great applications in the industry given that other pectinolytic enzymes and different enzymes can exist in the extract. These are already being used in the industry as a mixture in order to increase the process efficiency. Also, the high cost of enzyme purification procedures makes the crude extract preferable.

\section{Conclusion}

After biochemical and thermal characterization of the crude enzyme it seems that this enzyme could be a potential candidate for applications primarily in food, waste treatment centres, paper and textile industries. As a polygalacturonase from a strain, not previously considered for this purpose, it is a new example. With the promising results obtained, it may also be considered as an alternative to the commercial strain, $A$. niger. Discovering new enzymes with novel properties is a difficult task. Hence enzymes from new sources may have considerable economic values, which should not be ignored.

\section{Acknowledgement}

Financial support of Izmir Institute of Technology is gratefully acknowledged.

\section{References}

Bhatti, H. N., Asgher, M., Abbas, A., Nawaz, R., \& Sheikh, M. A. (2006). Studies on kinetics and thermostability of a novel acid invertase from Fusarium solani. Journal of Agriculture, Food and Chemistry, 54, 4617-4623.

Dogan, N., \& Tari, C. (2008). Characterization of three-phase partitioned polygalacturonase from Aspergillus sojae with unique properties. Biochemical Engineering Journal, 39, 43-50.

Gadre, R. V., Driessche, G. V., Beeumen, J. V., \& Bhat, M. K. (2003). Purification, characterization and mode of action of an endo-polygalacturonase from the psychrophilic fungus Mucor flavus. Enzyme Microbial Technology, 32, $321-$ 330.

Georis, J., Esteves, F. L., Brasscur, J. L., Bougnet, V., Devreese, J. L. B., \& Giannotta, F., et al. (2000). An additional aromatic interaction improves the thermostability and thermophilicity of a mesophilic family xylanase: Structural and molecular study. Protein Science, 9, 466-475.

Gogus, N., Tari, C., Unluturk, S., Oncu, S., \& Tokatlı, F. (2006). Investigation of the relationship morphology, rheology and pectinase production by Aspergillus sojae 20235 in submerged cultures. Biochemical Engineering Journal, 32, 171-178.

Gummadi, S. N., \& Panda, T. (2003). Purification and biochemical properties of microbial pectinases - A review. Process Biochemistry, 38, 987-996.

Hoondal, G. S., Tiwari, R. P., Tiwari, T., Dahiya, N., \& Beg, Q. K. (2002). Microbial alkaline pectinases and their applications: A review. Applied Microbiology and Biotechnology, 59, 409-418.

Jayani, R. S., Saxena, S., \& Gupta, R. (2005). Microbial pectinolytic enzymes: A review. Process Biochemistry, 40(9), 2931-2944.

Kashyap, D. R., Vohra, P. K., Chopra, S. R., \& Tewari, R. (2001). Applications of pectinases in the commercial sector: A review. Bioresource Technology, 77 215-227.

Kaur, G., Kumar, S., \& Satyanarayana, T. (2004). Production and characterization and application of a thermostable polygalacturonase of a thermophilic mould Sporotrichum thermophile Apinis. Bioresource Technology, 94, 239-243.

Laemmli, U. K. (1970). Cleavage of structure proteins during the assembly of the head of bacteriophage T4. Nature, 227, 680-685.

Lowry, O. H., Rosebrough, N. J., Farr, A. L., \& Randall, J. R. (1951). Protein measurement with the folin phenol reagent. Journal of Biology and Chemistry, 193, 265-275.

Moyo, S., Gashe, B. A., Collison, E. K., \& Mpuchane, S. I. (2003). Optimising the growth conditions for the pectinolytic activity of Kluyveromyces wickerhamii by using response surface methodology. Journal of Food Microbiology, 85, 87-100.

Naidu, G. S. N., \& Panda, T. (2003). Studies on pH and thermal inactivation of pectolytic enzymes from Aspergillus niger. Biochemical Engineering Journal, 16 57-67.

Ortega, N., de Diego, S., Perez-Mateos, M., \& Busto, M. D. (2004). Kinetic properties and thermal behavior of polygalacturonase used in fruit juice clarification. Food Chemistry, 88, 209-217.

Panda, T., Naidu, G. S. N., \& Sinha, J. (1999). Multiresponse analysis of microbiological parameters affecting the production of pectolytic enzymes by Aspergillus niger: A statistical view. Process Biochemistry, 35, 187-195. 
Saito, K., Takakuwa, N., \& Oda, Y. (2004). Purification of the extracellular pectinolytic enzyme from the fungus Rhizopus oryzae NBRC 4707. Microbiological Research, 159, 83-86.

Sakamoto, T., Bonnin, E., Quemener, B., \& Thibault, J. F. (2002). Purification and characterization of two polygalacturonases from Aspergillus niger able to degrade xylogalacturonan and acetylated homogalacturonan. Biochimica et Biophysica Acta, 1572, 10-18.

Shuler, M. L., \& Kargi, F. (2002). Bioprocess engineering basic concepts (2nd ed.) Prentice Hall. pp. 77-78.
Singh, S. A., \& Rao, A. G. A. (2002). A simple fractionation protocol for and a comprehensive study of the molecular properties of two major endopolygalacturonases from Aspergillus niger. Biotechnology and Applied Biochemistry, 35, 115-123.

Tari, C. Gogus, N., \& Tokatlı, F. (2007). Optimization of biomass, pellet size and polygalacturonase production by Aspergillus sojae ATCC 20235 using response surface methodology. Enzyme Microbial Technology, 40, 1108-1116.

Ustok, F. I., Tari, C., \& Gogus, N. (2007). state production of polygalacturonase by Aspergillus sojae ATCC 20235. Journal of Biotechnology, 127, 322-334. 